\title{
DSM-5 Paraphilic Diagnoses and SVP Law
}

\author{
Douglas Tucker $\cdot$ Samuel Jan Brakel
}

Published online: 5 January 2012

(C) Springer Science+Business Media, LLC 2011

In various discussions and debates about the proposed diagnostic categories for psychosexual disorders in DSM-5, a concern has been expressed that including expanded or new paraphilic diagnoses will lead to increased civil commitment under the Sexually Violent Predator (SVP) statutes that exist in 20 states (Frances, 2010; Franklin, 2010; Zander, 2008; Zonana, 1997).

It is important for those involved in these discussions to understand that no SVP statute requires that the "qualifying mental abnormality or personality disorder" be specifically based upon a DSM diagnosis. The various state courts and the U.S. Supreme Court are all in agreement that so long as it is proven that a mental abnormality is present and linked with the prediction of further acts of sexual violence, then it does not matter what the mental abnormality is called. The courts are quite aware that the DSM is an evolving document which draws on advancing clinical data. The critical point from the legal perspective is that mental health clinicians who testify in good faith as to a mental abnormality are able to identify sexual pathologies that are conceptually and empirically meaningful, regardless of whether they are listed in the DSM.

The U.S. Supreme Court clearly articulated this approach in its landmark decision upholding the constitutionality of Kansas'

D. Tucker

Program in Law and Psychiatry, Department of Psychiatry, University of California San Francisco School of Medicine, San Francisco, CA, USA

D. Tucker $(\square)$

2930 Domingo Ave., \#306, Berkeley, CA 94705, USA

e-mail: dtuckermd@gmail.com

S. J. Brakel

DePaul University College of Law, DePaul University,

Chicago, IL, USA
SVP statute (Kansas v. Hendricks, 521 U.S. 346, 117 S.CT. 2072 [1996]), which is identical to most of the other SVP statutes in the United States. The Court's opinion (at p. 359) states that " $[\mathrm{T}]$ he term 'mental illness' is devoid of any talismanic significance. Not only do psychiatrists disagree widely and frequently on what constitutes mental illness, but the Court itself has used a variety of expressions to describe the mental condition of those properly subject to civil confinement....Indeed, we have never required state legislatures to adopt any particular nomenclature in drafting civil commitment statutes. Rather, we have traditionally left to legislators the task of defining terms of a medical nature that have legal significance....Often, those definitions do not fit precisely with the definitions employed by the medical community."

\section{References}

Frances, A. (2010). The forensic risks of DSM-V and how to avoid them. Journal of the American Academy of Psychiatry and the Law, 38, $11-14$.

Franklin, K. (2010). Hebephilia: Quintessence of diagnostic pretextuality. Behavioral Science and the Law, 28, 751-768.

Zander, T. K. (2008). Commentary: Inventing diagnosis for civil commitment of rapists. Journal of the American Academy of Psychiatry and the Law, 36, 459-469.

Zonana, H. (1997). The civil commitment of sex offenders. Science, $278,1248-1249$. 